\title{
Offender Theme Analyses in a Crime Narrative: An Applied Approach
}

\author{
Reshmi Dutta-Flanders ${ }^{1}$ (D)
}

Published online: 18 November 2017

(C) The Author(s) 2017. This article is an open access publication

\begin{abstract}
There is a great deal of research on the structure of narrative and its mode, and on the narrative positioning and counter positioning of the actor in legal and social contexts. In offender narratives, personal experiences are embedded for observation and analysis of particular realities that contextualize a disposition of the perpetrator being 'an undergoer' rather than an 'effector' of actions. This is evaluated in the shift from a narrated action to a speaker utterance in prospection and also in anticipation of the criminal act. Using 'grammatical logic', it is also possible to demonstrate how the crucial event (the crime) is not a cause, but an effect of a personal theme that encapsulates pattern of circumstances when the narrative outcome in criminal narrative becomes the product of its discursive practices. This is the 'story of intentionality' (my term) in crime narratives, characteristically embedded within the 1 st the story of crime, the 2 nd is the story of investigation [14, 20]. Using techniques from functional grammar and critical stylistics for discourse analysis, I intend to show an effective approach for the search of offender theme that underlies an act of crime. These disciplines provide the analyst with the linguistic material to analyse intersentential cohesion in a chain of semantically linked sentences (in written or spoken discourse) that explore the ways in which things are 'made to look' in the structure and functions of the English language. As a case study, I am using an offender narrative from Tony Parker's book Life After Life: Interviews with Twelve Murderers (1990) showing an effective approach for the search of personal themes underlying the act of crime. Offender theme analyses are also valuable for evaluating the changing nature or development of offender characteristics pre or post crime.
\end{abstract}

Reshmi Dutta-Flanders

R.Dutta-Flanders@kent.ac.uk; reshmidf@gmail.com; http://www.kent.ac.uk/secl/ell/staff/dutta-flanders.html; http://cbconsultant.education/committes

1 English Language and Linguistics, School of European Culture and Languages, University of Kent, Canterbury, Kent CT2 7NF, UK 
Keywords Grammatical logic Theme - Counterfactual inference $\cdot$ Hypothetical premise $\cdot$ Double dipping $\cdot$ Participant roles $\cdot$ Criminal intent

\section{Introduction}

The 'story of intentionality' (my term) or 'intent' is about motivation that stems from the outcome of one's personal experiences and circumstances. This outcome in Jonathan Culler [3] is in the way of establishing a hierarchy of events,

'in which the functioning of narratives ... [manipulates the narrative outcome] by presenting events not as given but as the product of [its] discursive forces.'

For instance, the story of Oedipus ${ }^{1}$ is about discovering the signification (meaning) of the fateful events of him killing his father Laius and ending up marrying his mother Jacosta.

As in detective stories, the revelation of Oedipus being the murderer of his own father is the story, but the significance (importance) of this determinate event is in the revelation of a prophecy. ${ }^{2}$ The 1 st logic behind Oedipus killing his own father must converge with the 2 nd logic, i.e. the meaning relating to the coming about of a prophecy in the first-place due to Laius' past deeds. It is not the act of killing that determines the meaning, but is the search for the signification that leads readers to converge the effect (the significance) of Laius' prior deed with the 'coming about' of the prophecy (a cause due to the effect of Laius' past deeds) by murdering his own father and consequently the narrative outcome-Oedipus' tragic stature; such is the narrative theme in the case of offender narrative.

Discursive ${ }^{3}$ forces in offender narrative make it essential that, in the interweaving of events in the discourse, the narrative focus counters the criminal intent or desire which is to be investigated and revealed; the intent is to be treated as a product of the discursive force in which the crime as an outcome is an effect of theme [3]. By identifying the order and perspective in which the narrative events are represented, the analyst is able to interpret the product of its discursive forces in the requirement

\footnotetext{
${ }^{1}$ Evidence suggests that the chronological order of the plays based on the saga of Thebes is, Antigone was first (442 BC), next Oedipus the King (after 430 BC) and Oedipus at Colonus last (produced after Sophocles' death) [24].

2 Sophocles' version is that the prophecy told by Apollo at Delhi was that any son of Laius and Jacosta, the king of Thebes, would kill its father. They sent their infant out to die on the mountain side, but the shepherd who was supposed to abandon the child took him to Polybus and Merope, king and queen of Corinth, who were childless and they adopted this child and named him Oedipus, the swell-foot. When Oedipus was a grown man, he was told by an old man that he was not the son of the royal house. When he went to Delphi to ask Apollo, Oedipus was told of the prophecy. Oedipus decided not to return to Corinth, instead of going home southeast, he went east and on his way quarrelled with an old man in a wagon and defended himself when attacked, killing the old man who was, his father Laius. Oedipus came down to Thebes, where the citizens were oppressed by monster Sphinx. The monster would leave them alone only when she got an answer to her riddle. Oedipus answered the riddle and as a reward got the throne of Thebes and the hand of Jacosta. When plague struck the city of Thebes, the Delphic oracle declared it would cease only when the murderer of Laius was found to be exiled and executed. On investigation, Oedipus discovered his true identity and recognized that the prophecy was fulfilled that was made to him at Delphi. Jacosta hanged herself, Oedipus put out his eyes with pins from her robe and left Thebes [24].

${ }^{3}$ Discursive - proceeding by reasoning or argument rather than intuition.
} 
of Oedipus' tragic stature over his crime. The narrative effect emphasises the causal force of past experiences manifesting offender themes ${ }^{4}$ (my term) in,

Offender scenarios, such as

Prior to a crime (e.g. a bully, undermining self, solitary disposition, suicidal, grudge)

Relating or corresponding to the crime (e.g. offender rationale)

Premeditated action (e.g. as solution to personal circumstances)

The coming about of crime, such as,

Diminished responsibility (e.g. callousness)

Being a victim rather than an offender (a narrative object)

Offending behaviour (the justification)

Following sentencing, the outcomes such as,

The distancing act (the acceptance period)

The dual person (retiring-into-a-shell vs. the trouble maker)

Coping mechanisms (e.g. temporarily homosexual)

The offender moral: conscientious, being fair and loyal

Self-identity, confidence

\section{Framework}

The analysis of offender theme is about the way a contrary logic resists the logic of signification in which events are conceived as prior to their discursive representation. For instance, a prior event has made Oedipus guilty, and when this is revealed he attains tragic disposition in accepting its meaning. However, a contrary logic resists this logic by arguing that being his father, Oedipus cannot kill him; therefore, more evidence is necessary for Oedipus to acquire his tragic status. The force of the narrative relies on a contrary $\operatorname{logic}{ }^{5}$ in which the event is not the cause but an effect of theme.

\footnotetext{
4 The offender theme is what influences criminality. It is not the crime that defines the criminal, but it is the influences before and after the crime, or personal circumstance that thematises the crime, making crime, not the cause but an effect of a theme that links to an offender background that is changing or developing pre-and post-crime.

5 Contrary logic - in which an event is not a cause but an effect of theme. To describe this logic is not to quibble over details but to investigate tragic power (Culler 175). In Freud, the logic of signification (logic 1 ) is one in which events are conceived as prior to their discursive representation-the priority of event over meaning. E.g., a prior event has made Oedipus guilty, and when this is revealed he attains tragic disposition in accepting the meaning imposed by the revealed event. However, there is a contrary logic (perspective/logic 2) which resists the logic of signification by arguing that being his father Oedipus cannot kill him (the contrary logic), therefore more evidence is necessary for Oedipus to acquire his tragic status, hence the force of the narrative relies on the contrary logic, in which event is not a cause but an effect of theme. The play (narrative) thus brings to light a deed which is so powerful that it imposes its meaning irrespective of any intention of the actor. These two logics cannot be bought together in harmonious synthesis: each works by the exclusion of the other; each depends upon a hierarchical relation between story and discourse which other inverts.
}

(my emphasis) (Culler 1981: 175). 


\subsection{Textual Function}

The meaning of the effect of past experiences is best evaluated in the metafunction in clauses in a criminal discourse where meaning and function come together by starting with a clause as the message; where the different kinds of meaning are realized in different metafunctions [1]: experiential, interpersonal, textual and logical (Table 1). For this study, I am focusing on the textual function in the clause as a message, because a participant role (typically realised by nominal group) is not a random variation; in textual function participant role creates relevance to context [12] by assigning prominence in an utterance as in examples 10-17 below.

Participant functions in textual metafunction may be semantically an Agent (a structural function or embodying feature of Agency), a Beneficiary (for whom the process took place) or a Range (that specifies the scope of the process); these roles can be mixed when having some features of the participant and some features of Circumstance (typically realized by an adverbial group or prepositional phrase), entering into the clause directly, participant-like as the nominal group, or indirectly circumstantial-like in prepositional phrases. Circumstance (footnote 5), unlike a nominal group, can be indirectly agentive (footnote 8) causing an action, while Actor role is more direct and volitional.

My focus is on participant function entering into the clause indirectly circumstantial-like ( $\mathrm{C}$ element) in clause-initial position. If a participant is in the place of prominence in the message, such as in examples 5-7 in Table 2 [Note: A (Actor/Initiator), C (Circumstance ${ }^{6}$ ), M (Medium ${ }^{7}$ ), P (Process), G (Goal ${ }^{8}$ ), (Ag) Agent ${ }^{9}$ ], it tends to take a preposition (see column, 'marked Theme' ${ }^{10}$ ), and is construed as an 'indirect' participant. Similarly, the information in the C element acquires a special status in the clause as a message reinforced by the presence of a preposition and also as a marked theme providing circumstantial information, answering questions like, 'who by' in 5, 'to whom' in 6 , and 'in what condition' in which the process occurs in 7 [19].

Hence,

\footnotetext{
${ }^{6}$ Circumstantial (C) elements provide information about: manner/how, location/point in time, extent/duration/how long/how often, quality/expressed by adverbs, means/by what means/with what, cause/why, comparison/what ... like, degree/how much, cause (includes reason/as a result/why, purpose/ what for, and behalf/who for), angle/point of view). (Thompson 2014: 116).

${ }^{7}$ Participant Medium is not the doer nor the causer but a nodal participant critically involved in some way or other with the process. (Halliday 1994: 165).

${ }^{8}$ An entity is a Goal through the Medium of which the process comes into existence.

9 Agent is the external Agency. In material process, e.g. I (A) stole (P) sweets (G), it is the Actor who is the Initiator of the process and has a Goal (Transitive), otherwise it is the Instigator of the Process (Intransitive) e.g. I ran, where the cause of running is outside the given clausal structure. In Mental process (think, suppose, mean), the Agent is a Senser role, e.g. I (Senser) mean (Process) I was guilty (Phenomenon) and the process in the clause is encoded in one direction, from phenomenon to consciousness and not the other way around.

10 Theme-a clause is organized as a message by having special status assigned to its parts. One element is the Theme, this then combines with the other part the Rheme of the clause, so that the two parts together constitute a message. Theme is the part that gives the clause its character as a message known as Thematic structure. First position of the clause defines the function of Theme realized in the grammar of English as a nominal group, adverbial or prepositional phrase. (Halliday 1985: 37-38).
} 
Table 1 Metafunction

\begin{tabular}{|c|c|c|c|}
\hline Metafunction & Kind of meaning & Status of clause & Clause structure \\
\hline $\begin{array}{l}\text { Ideational: } \\
\text { Experiential }\end{array}$ & $\begin{array}{l}\text { Construing a model } \\
\text { of experience }\end{array}$ & $\begin{array}{l}\text { Clause as representation } \\
\text { Emphasize the cause-\&-effect } \\
\text { aspect of processes by comparison } \\
\text { with the deed-\&-extension one }\end{array}$ & $\begin{array}{l}\text { Segmental (based } \\
\text { on constituency) }\end{array}$ \\
\hline Interpersonal & $\begin{array}{l}\text { Enacting social } \\
\text { relationships }\end{array}$ & Clause as exchange & Prosodic \\
\hline Textual & $\begin{array}{l}\text { Creating relevance to } \\
\text { context }\end{array}$ & Clause as message & Culminative \\
\hline $\begin{array}{l}\text { Ideational: } \\
\text { Logical }\end{array}$ & $\begin{array}{l}\text { Constructing logical } \\
\text { relations }\end{array}$ & Clause as representation & Iterative \\
\hline
\end{tabular}

(Halliday 1994: 36, 167, 172)

Table 2 Textual prominence

\begin{tabular}{|c|c|c|c|c|}
\hline & Point of view & Non-prominent & Marked theme & Late news \\
\hline 5 & $\begin{array}{l}\text { Actor (A) } \\
\text { (her nephew) } \\
\text { Transitive }\end{array}$ & $\begin{array}{l}\text { Her nephew }(A) \text { sent } \\
(P) \text { her }(G) \text { flowers }\end{array}$ & $\begin{array}{l}\text { By her nephew }(\mathrm{Cl} \\
\text { accompaniment) she }(\mathrm{M}) \text { was } \\
\text { sent flowers }(\mathrm{O})\end{array}$ & $\begin{array}{l}\text { She was sent } \\
\text { flowers by her } \\
\text { nephew }\end{array}$ \\
\hline 6 & $\begin{array}{l}\text { Beneficiary } \\
\text { (his aunt) } \\
\text { Transitive }\end{array}$ & $\begin{array}{l}\text { He }(\mathrm{A} / \text { Initiator }) \text { sent } \\
\text { his aunt flowers }\end{array}$ & $\frac{\text { To his aunt }}{\text { flowers }}$ (C/location) he sent & $\begin{array}{l}\text { He sent flowers to } \\
\text { his aunt }\end{array}$ \\
\hline 7 & $\begin{array}{l}\text { Range } \\
\text { (the high jump) } \\
\text { Transitive }\end{array}$ & $\begin{array}{l}\text { John wins the high } \\
\text { jump every time }\end{array}$ & $\frac{\text { At the high jump }}{\text { John wins every time }}$ & $\begin{array}{l}\text { John wins every } \\
\text { time at the high } \\
\text { jump }\end{array}$ \\
\hline 8 & $\begin{array}{l}\text { Actor } \\
\text { (Mary) } \\
\text { Transitive }\end{array}$ & Mary sailed the boat & $\begin{array}{l}\text { The boat }(\mathrm{M}) \text { sailed }(\mathrm{P}) \\
\mathrm{M}+\mathrm{P} \\
\text { (Middle clause) }\end{array}$ & $\begin{array}{l}\text { The boat }(\mathrm{C}) \text { was } \\
\text { sailed by Mary } \\
\text { (M) }\end{array}$ \\
\hline
\end{tabular}

(Halliday 1994: 164, 168 with some alterations)

Prominence in the message ...[is] functioning either (i) as a marked Theme (and not Subject) or (ii) as 'late news' - that is, occurring after some other participant or circumstance, that already follows the Process. In other words, prominence comes from occurring either earlier or later than expected in the clause; and it is this that is being reinforced by the presence of the preposition. The preposition has [thus] become a signal of special status in the clauses as the message. (my emphasis) [12]

Prominence is also reinforced as a Middle clause $(\mathrm{M}+\mathrm{P})$ without the presence of a preposition. For instance, as late news, The boat (is a Goal in the transitive reading of example 8) is topicalized not as a Subject, but as an entity (an object undergoing the Process) with Medium role through which the process of sailing is actualized due to an external doer/Actor/Initiator Mary (Table 2: column non-prominent). Note that Mary is also an Agent/Instigator of Process, and can be outside the constellation of a Middle clause structure. Thereby, The boat in Medium role is not a subject, but 
a Theme that is about sailing (possibly for the first time), actualised by Mary (an Agent) who is instigating the process of sailing. As late news Mary features Agency and is also an engaged participant who manipulates the process of sailing. Mary is a structural Agent in Middle clause structure.

Let's now compare example 8 with example 10, where offender Danny in subject position is the Actor providing the Process of stealing. The $\mathrm{C}$ element in 10, sweets from shop .... is 'late news' and is part of the predicate in the subject predicate constellation.

\section{Norm:}

10. (extract a: line 3) Offender Danny: I (Actor/Initiator) used to steal $(\mathrm{P})$ sweets

(G) from shops $(\mathrm{C})$ but I $(\mathrm{S})$ mean $(\mathrm{Ph})$ all kinds do that don't they?

$\mathrm{A} /$ Initiator $+\mathrm{P}+\mathrm{G}+\mathrm{C} \ldots$...

(Transitive point of view)

\section{Deviation:}

Conversely, in 11 and 12 ("Appendix", extract c: line 27 and 28), the pronoun ' $I$ ' is an entity (a victim of committing a crime on impulse), and becomes prominent in Medium role who is not the same narrating-I in 10, but an entity in 11 and 12, and following the grammatical logic is functioning NOT as a subject but as a marked Theme (i.e. prominent) in the clause.

\section{Marked Theme:}

11.

12.

13.

14.

15.

(Manipulative causation)

16.

(Analytical causation)

17. (cl. 27) Offender Danny: I ran out of the house because I was very very frightened

$$
\mathrm{M}+\mathrm{P}+\mathrm{C}
$$

(Ergative point of view)

(cl. 28) Offender Danny: I ran like buggery

$$
\mathrm{M}+\mathrm{P}
$$

(Ergative point of view)

If you had listened to me, you wouldn't have made mistakes (but you didn't listen to me)

\section{[Counterfactual premise]}

If you listen to me, you wouldn't make mistakes,

but I don't suppose you will listen to me

\section{[Hypothetical premise]}

John (Ag/Instigator/causer) opened (P) the door (M)

(Ergative Point of view)

John (Actor/Initiator) threw (P) the ball (Goal)

(Transitive point of view)

Mary (Instigator) changed (P) John (Medium), but it took her a whole life time to bring it about (C)
[Schema b: Actor-Goal]

15b. The door (M) opened

[Schema a: InstigatorMedium]

[Schema c: Actor-Affected] [6] 
In the above examples, from a transitive point of view ${ }^{11}$ the direct participants are, Actor $\rightarrow$ Goal and the extension is linear. On the other hand, from an ergative point of view ${ }^{12}$ [12], there is another participant function (an Instigator) or circumstance with Medium role thematising (or topicalizing) causation. The causation is manipulative, such as in example 16, where (causer) Mary is the instigator of the process and John is the Medium through whom the change is actualized. While in example 15b, The door $(\mathrm{M})$ opened $(\mathrm{P})$, the instigator of the process, John, is external and outside the clausal constellation making the structure non-linear. Because causation (due to John in 15a) like circumstance adds a feature of agency and surrounds the additional participant function of an a Medium through whom the act of opening is actualized. Also, inanimate entity, the door in 16 is indirectly involved in the process. Similarly, in 11 and 12, the effect of fright due to the murder, is a circumstance that surrounds the additional participant function of Danny as an Agent, who is running for fear of being caught by the police, and is an entity, a victim of his action (the murder). Thus, the circumstance surrounding additional participant function of Danny is indirectly made prominent in the Medium role, formulated due to an external cause that initiated Danny to run from the crime scene.

The difference thus between transitive and ergative interpretation is to whether or not there can be an analytic causative with the process (John (Actor/Initiator) threw (P) the ball (Goal) [Schema b: Actor-Goal]). Otherwise causation is manipulative due to participant function such as an Instigator (John (Ag/Instigator/causer) opened (P) the door (M) [Schema a: Instigator-Medium], or as a Medium participant function, I (M) ran (P) out of the house (C) [Schema c: Actor-Affected] in ergative point of view. Note that $\mathrm{M}+\mathrm{P}$ constellation is an intransitive clause. In offender narrative, the analyst's concern is of the external cause that is backgrounded such as in intransitive structures, which becomes foregrounded when considering the

11 Transitive point of view-Transitive clause is a linear interpretation. The function in the clause is defined by extension in the way of a Goal and emphasizes the distinction between the direct participants Actor and Goal only.

E.g. Mary (Actor) made Fred (Goal) roll the ball (C). This structure is configurational and cannot be extended like the ergative structure below. It introduces the participant function of an Actor/Initiator to account for an executive role in a linear clausal structure. (Halliday 1994:172).

12 Ergative point of view - the clause adds a feature of agency. The structure is open-ended, and a further round of agency can be added on. The clause consists of both a Medium and Agent e.g., 'a' does something to ' $\mathrm{x}$ ', and ' $\mathrm{a}$ ' makes ' $\mathrm{x}$ ' do something.

E.g. John (Agency) got Mary (Agency) to make Fred (M) roll the ball. (Halliday 1994: 172)

The ergative is a nuclear interpretation and the nucleus of $\mathrm{P}+\mathrm{M}$ has an inner ring of additional participants as well as an outer ring of circumstances (John got Mary to make Fred ...) surrounding it.

The difference between ergative and transitive interpretation is whether or not there can be an analytic causative with process, make, as in,

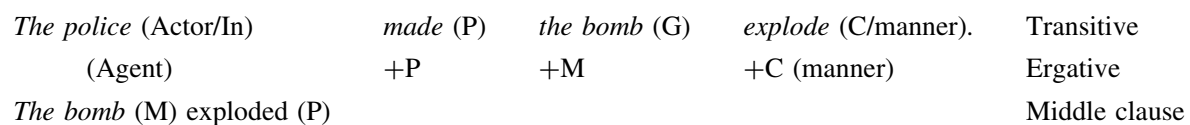


additional participant functions for an intransitive Actor in a $\mathrm{M}+\mathrm{P}$ clausal structure (like examples 11 and 12).

Unlike clause 10, the textual functions in clauses 11 and 12 are non-linear, where the intransitive Actor does not provide the action; these clauses have an inner ring of additional participants that consist of both Agent and Medium, and an outer ring of circumstances surrounding the additional Agency functions such as, Actor John got Mary (Medium + Agent) to make Fred (Medium) roll (Process) the ball (Goal)) (see footnote 10 and 11). In this clause, Mary surrounds the participant function of Fred in Medium role through whom the Process of 'rolling the ball' is actualized. Similarly, in clauses 11 and 12, an outer ring of circumstance caused by fright makes Danny run from the crime scene, therefore pronoun ' $\mathrm{I}$ ' in cl. 11 and 12 is a post murder experiencing self of Danny, different from its core self in 10.

Like above, in the textual function and also in the orientation of a narrating-I (in modal sense in clauses) the vantage points ${ }^{13}$ that ensue in the analysis of extracts a-c below, present the narrating-I as a counterfactual or a hypothetical participant with reference to its crime.

\subsection{The Counterfactual and Hypothetical Premise}

Notice the 'if then' expression underlined in Danny's statement,

43. I am the sort of person who if he's in a situation, a job, a prison sentence or whatever it is, he likes to get on with it to the best of his ability and not have hassle or give it either. (p. 11)

44. If people take me like I am, I won't give anybody trouble, you don't give us no trouble and we won't give any to you.

The analyst is compelled to ask, did Danny by his own admission in clauses 43 and 44, kill his grandfather after all, in Danny's words, 'for giving him hassle' when he did not fulfil his request? Was Danny in denial of his inability to control his temper and therefore used the word accident (extract a: cl. 9, 16) repeatedly, so as not to appear that it was a consequence of his alcohol addiction (extract a: cl. 25)? The stylistic feature of repetition is used more commonly in offender discourse.

Furthermore, when describing himself NOT as a hardened criminal (extract b: cl. 43-47), the iterative use of rhetorical questions ${ }^{14}$ expresses his inability to realise his anger problem as the aggressor trigger behind the killing (as pointed out in the St Andrews correction centre in extract c: cl. 40-42). Use of rhetorical questions is a persuasive strategy for self-manipulation as in management discourse [15]. Additionally, in the modal senses: could, should, would (deontic sub-storyworld) and in Senser participant role in mental processes: suppose, mean, think (epistemic

\footnotetext{
13 Vantage point-Normally narrators speak from a vantage point at a specific time and describe the goings on, as an omniscient narrator who knows everything, or as an external narrator who reports only what is invisible and uninvolved character present on the scene might reasonably notice, and sometimes as an involved character at the time it occurred. [16:156].
}

14 Rhetorical question - in management it is a type of persuasive discourse strategy, where there is concealment of managerial self-serving motives when presenting information. 
sub-storyworld) underlined in extracts ("Appendix"), foreground Danny's focus with reference to crime, indexing readers contextually to, 'the coming about of crime'.

Hypothetical premise ${ }^{15}$ in the modal sense along with counterfactual inferences such as negation and the conditional 'if', together constitute an alternate world in Danny's account, that enables one to find further evidence of an offender theme of 'diminished responsibility' ${ }^{16}$ in the implied falsity. For instance, look at the nature and the form of indicators associated with counterfactuality similar to examples in marked themes, 13 and 14 above,

Implied falsity in conditional if, or implied rejection of the conditional premise,

18. If you had listened to me, you wouldn't have made mistakes (but you didn't listen to me).

As opposed to a hypothetical premise in futurity underlined,

19. If you listen to me, you wouldn't make mistakes, but I don't suppose you will listen to me.

If Counterfactual inferences are utterances that are contrary to the known fact, and therefore are not true assertions [6], then counterfactual is also an alternate world that is viewed with hindsight [4]. All counterfactual meaning is pragmatically implied. Counterfactuality is not equivalent to lying, but an intention of concealing the contravened known facts from the hearer [6]. (my emphasis)

On the other hand, in hypothetical implicature a predicative meaning is intensified over a counterfactual utterance. By undercutting the lexical sense of volition and intention in hypothetical modals such as, could and shall, when appearing alongside counterfactual inferences in negation and conditionals, these features linguistically formulate, in the distinction between a counterfactual and an alternate hypothetical world, a binary pair of events constructed such as a factual one and a hypothetical other (with the counterfactual inferences), as we shall see in the analysis of Danny's account in extracts a-c.

Let's take up the case of offender Danny Morgan from the book of true criminal narratives, Life After Life: Interviews with Twelve Murderers (1990) by investigative journalist, Tony Parker.

\section{Analyses}

Case: Lifer Danny Morgan (on parole) was 14 years old when he killed his grandfather for not giving him pocket money after his mother had refused. Evaluation of three extracts (a-c) at micro level adopted from Danny's account are provided in the "Appendix": Tables 3-5.

\footnotetext{
15 In Dannenberg [5: 307] 'the issue of hypothetical is vital ... in its dynamic and contrastive interaction with events [it is] ... deemed to "really happen" in a narrative world." There is dichotomy of "narrator utterance' and 'character statement' [17: 88] when character's experience in hypothetical meaning is incorporated within its diegesis space as a narrator.

${ }^{16}$ Diminished responsibility - a plea under which proof of an impairing abnormality of mind is submitted as demonstrating lack of premeditation and therefore criminal responsibility. (Collins English Dictionary) Accessed: https://www.collinsdictionary.com/dictionary/english/diminished-responsibility 19th September 2017, $12.35 \mathrm{pm}$.
} 


\subsection{The Findings: Extract a}

Extract a is about contextualising the state of Danny 'NOT being a criminal, i.e. linguistically establishing the theme of 'diminished responsibility'. The subject positioning of a narrating-I (e.g. cl. 3, I used to steal, and cl. 9. I'd say) is intransitive in a transitive point of view, but agent-oriented in an ergative point of view. With an intransitive Actor (who is not an Initiator and provides actions like steal and say); the function is more manipulative causative (Schema c: Actoraffected), and not analytic causative in a transitive structure (Schema b: ActorGoal). This can be argued as; intransitive clauses are more state-oriented (Schema c) than dynamic (Schema b). Additionally, a dominant Actor/Initiator narrating-I in Senser role (I mean in cl. 37 and I suppose in cl. 22) is more about an 'experiencing self', where the 'me' of participant Danny is set in opposition to his initiative self ( $I$ used to steal sweets), countering the effects of feeding his drinking habit that caused him to kill his grandfather. He is demonstrating a 'lack of premeditation and therefore criminal responsibility' over premediated murder according to the definition for 'diminished responsibility' from Collins dictionary (footnote 14).

In counterfactual inferences, Initiator Danny constitutes a countering narrative [2] where the narrating-I is functioning as a Senser and also simultaneously as an entity (a narrative object) with Medium role through whom the personal circumstance of Danny's drinking habit is accounted for in the discourse. This is a feature of double dipping (in criminology) for multipositionality to fulfil different objectives of the narrating-I. The simultaneous participant functions in Senser and Medium role in clauses, are due to Danny's surrounding personal circumstance (like stealing to feed his alcohol addiction). Such are the linguistic characteristics of offender Danny's experiencing self in the discourse, also found in my wider research on criminality in the narrating act of double function ${ }^{17}$ of tense aspects that provide value to Danny's present state against his backgrounded contrast in tense aspects, e.g. in perfective aspects about being an addict in cl. 22, 23 in extract a. Also, in progressive aspect a necessary condition is provided in cl. 19 lying and in cl. 21 striking for causation, and like the present tense form ' $d o$ ' in $5 \mathrm{a}$ (extract b) justify/instigate/trigger the act of killing his grandfather. Using such narrating act [6], Danny accommodates multiple foci in the simultaneous discourse functions of an Agent and Medium roles of a narrating-I, or a Senser role for the cognitive transformation of Danny's criminal behaviour. Danny thus is a narrative object in his narrative account through whom the topicalization of his personal circumstance for the offender theme of 'diminished responsibility' becomes prominent.

In Criminology, the simultaneity of participant position in the discourse is termed as double dipping, where the problem of multipositionality (as Senser and

\footnotetext{
17 Double Function is where the present is given value against the backgrounded contrast in past tense. A withheld circumstance is indexed in the tense shift for content gap in narrator discourse. Similarly, in simultaneous participant roles (e.g., Senser, Medium role for default Actor role in Danny Morgan narrative) there is double disposition of an experiencing self of the principal narrator Danny, embedded within its principle narrator disposition as a lifer/murderer. This is for displacement of focus as a Senser or an entity with Medium role rather than the vantage points of the same participant in a narrating disposition. (Dutta-Flanders 2014: 153).
} 
intransitive Actor in Danny's narrative) is tackled to accommodate the multiplicity of connections between entities, which are grounded to different objectives that an individual need to fulfil [6]. In literary criticism, such parallel narration in the story of crime is described as,

A polygenetic approach, in which the literary evolution of a new type of writing takes place. [18]

\subsection{The Findings: Extract b}

Extract $\mathrm{b}$ is about contextualising criminality: the state of Danny being a criminal. The narrating-I in this extract is countering in aggressor triggers, the fact that Danny, who likes to get on with it to the best of his ability and not have hassle or give it either (cl. 43 and 44), can also become violent. As an undergoer, Danny's experiencing self is here in opposition to the violence associated with his anger (as an effector $h e$ ), and in counterfactual inferences the act of murder is emphasised more as a process of criminal development and change from what he was in clauses 3 and 4.

\subsection{The Findings: Extract c}

In extract c, Agentive Danny in clauses 27, 28 also 21 and 23, is an entity with Medium role; this is because a status (both in Agency and Medium participant function) is instigated due to the external cause fright, that made him run from the crime scene, even though he knew he will be found out (cl. 32). Danny as an entity with (an implied) Medium participant function is a narrative object through whom the actions of being remanded and then plead[ing] guilty come into existence. By implied falsity or rejection of his conditional premise, as in extract a, an intransitive Actor Danny is countering the 'killing' of his grandfather as being the cause of the effects of feeling hassled and becoming angry when he is unable to get money to feed his habit.

Also, in line with the structure for courtroom discourse, the above extracts are an elaboration and are about establishing the point of the 'coming about of the crime'.

Orientation-is about circumstance (who, when, where, what)

Core narrative - is about what happened with reference to what was said, seen or done

Elaboration - provides further details, clarification, explication of aspects of the core narrative

Point-establishes the significance of the narrative account, i.e., the guilt or innocence of the defendant and addressed directly to the jury [13]. 


\section{Conclusion}

In the analysis of the three extracts from Danny's account, there is alternate positioning [2] of himself in his narrative, where Danny attempts to portray himself not as a hardened criminal. A scenario for an offender theme of 'diminished responsibility' emerges in the linguistic analysis when the events are narrated as a binary pair of events in hypotheticality, but with counterfactual inferences in the conditional 'if' and in the negation of reality.

Consequently, the reader's overall assessment of Danny's account is negated or is a conditional reality. A theme of 'diminished responsibility' is also linguistically analysed, when in Senser role Danny's default disposition as an Actor/Initiator in the extracts formulate low topicality for Danny being a hardened criminal, enabling him in cognitive transformation (in a change of state), as an experiencing self, to counter his established facts and withdraw from the real world of crime. While remain ignorant or in denial of his aggressor triggers (like the anger problem or his impatience when being hassled), as pointed out at St Andrews correction centre. In this way Lifer Danny (who was released on parole) establishes for himself an additional discourse slot, an inter diegesis space (my term) [7] in his narrative account, for an identity that makes his perpetrator role distinct from himself as a person.

The process of countering his core self (like an effector-he in clauses like, 27, 28 and 43, 44 in each extract) to reiterate, is constituted in linguistic choices like,

- The progressive aspects ${ }^{18}$ in cl. 19, 21 and 37,

- The experiencing self as an undergoer in Senser role for low topicality of Danny being a hardened criminal

- The entity in Medium role topicalize/thematise Danny as a narrative object in the discourse.

Besides the above linguistic choices, additional participant functions of an intransitive Actor constitute an overall Actor-affected schema c (as in example 17 above) in the account, when an outer ring of personal theme (such as impatience in cl. 35) surrounds an inner ring of additional participant functions (of Agent + Medium) of a subject position intransitive Actor in the clauses as the message. ${ }^{19}$ Intransitive clauses are not linear with direct participants like Actor to Goal; the 'energy input' from an outer ring of personal circumstance add a feature of agency to the intransitive Actor in subject position. Such as in cl. 24, the external circumstance surrounding additional participant functions is about, if grandfather gave him the money .... Danny probably wouldn't have [murdered him], and in cl. 26, the circumstance relates to Danny not being able to keep [his] ... temper under control. In this way, a feature of (external) agency is instigated by personal

\footnotetext{
${ }_{18}$ Progressive aspect form causation [7] as a necessary condition, which is an effect necessary to justify/ instigate/trigger the killing. In Ziegler [23: 7], 'aspectual meanings conveyed by the speaker's decision, [such as in progressive aspects], ... refer to the action as [being] completed or not.

19 As illustrated in Kristin Davidse, in transitive model there is 'energy input' only at the level of the Actor, while in ergative model there is 'energy input' at two levels: that of Instigator within the outer ring and that of Medium within the inner ring [21].
} 
circumstance and added to an intransitive Actor role, the clause then consists of both Agent (' $a$ ' does something to ' $x$ ') and Medium ('a' makes ' $x$ ' do something) participant function in ergative point of view. In Danny's account, it is the personal circumstance (of being unable to feed his habit) that makes Danny impatient and angry; this anger then makes Danny lose his control and commit crime-a case of manipulative causation. ${ }^{20}$ In this way, transformation of one's experience (or a change of state) is analysed in participants functions like,

- a Medium within an intransitive Actor role, through whom the experience of having been remanded and then pleaded guilty is actualized, such as in cl. 35 and 36 (extract c).

- an Agent (Instigator) in cl. 43 and 44 (extract b) in subject position who is not an Initiator, but an entity (a narrative object) through whom the Process of losing his temper in cl. 45 is actualized, instigated by factors like not having money to feed his habit.

- an Actor role in cl. 45, when Danny does not give hassle or give trouble if his wishes or demands are fulfilled.

In this way, a backgrounded circumstance of an Actor as a feature of Agency or Instigator becomes prominent for the purpose of criminality. Additionally, in modal sense: could, should, would, though negated, a deontic ${ }^{21}$ storyworld $^{22}$ is constructed where effector Danny expresses his degree of obligation. The iterative use of rhetorical questions (cl. 3,17 ) as a discourse feature is also functioning as selfserving motives when Danny attempts to reinforce the murder as an accident in cl. 9.

A counter phenomenon is filtered in this way through an evolved logic of textual functions in clauses, which is different from a 'designed logic of mathematics'. By following the principles in functional linguistics and in transformational grammar (Appendix: Analysis), a logically woven and formally expounded construction of knowledge is achieved. As a result, the analyst can evaluate the psychological, the grammatical and logical functions in clauses, not possible when evaluating idealised

\footnotetext{
${ }^{20}$ Where the causee is involved as a non-volitional entity [such as Intransitive Actor, Medium], and the causer [the energy input due to personal circumstance and trait] physically manipulate the cause in effecting the caused event. Note that the notion of manipulative causation is traditionally expressed in lexical causative form. In my view effects of circumstance is also the causer that is instigated by personal traits [21].

21 Modal verbs can, should, must trigger a deontic-modal world. While, boulomaic modality expresses desire or wish triggered by verbs, want, wish. Verbs such as know, suppose, believe express epistemic orientation. These are 3 sub worlds of the text world within a discourse. Text world is created in the mind of each interlocutor who are in the same discourse world involving face-to-face discourse participants e.g. author, reader etc. in the actual world. The content of text world is inaccessible, it is only a character-accessible world unlike facts available for checking and verification in the discourse world [25].

22 Storyworld - there is the storytelling world and the storyworld. For example, after having narrated an incident of being held at gunpoint, the speaker explains to other listeners her inability to remember the person who was holding the gun to her head, and says, 'If it ever happens to you ...'. As continuation of exit talk, the speaker is making it clear her inability to remember what her assailant was wearing. But in the context of the story, in this swing phrase the speaker switches the talk back into the story in the pronoun you (the listeners) instead of the general you in the Storytelling world. My emphasis (Polanyi, in Tannen 165-6).
} 
clause structures that cannot be interpreted as what they really are as in natural living language [9]. Also in the analysis of one's experiences when transformed into meaning in clauses, enables the analyst to foreground an outer ring of personal circumstance as effect that surrounds the crime. Such as, the effect of personal themes of impatience and anger in the case of Danny allows us to focus any change and development in offender characteristics in the context of crime and criminality.

Finally, in identifying the perspective by which the narrative events are represented in linguistic analysis, the analyst is able to interpret the narrative's discursive forces in operation for a narrative requirement. In this instance, the narrative requirement is about perpetrator intent-i.e. countering of Danny's personal traits and circumstance as being the real focus in his account over his crime. And this narrative purpose is achieved in the counterfactual and hypothetical inferences that emphasise the causal force of Danny's past deeds which in turn manifest an offender theme of diminished responsibility over a premeditated criminal intent. This offender theme is also related to Danny's true sense of responsibility towards his alcohol and anger problems, foregrounded in a deontic storyworld of obligation. Furthermore, the trait of 'feeding one's habit' is an effect in criminal context, if remaining unmanaged, can cause Danny to reoffend, making the event not a cause but an effect of the theme (of coming about of crime due to callousness or being a victim of one's personal trait). Manifested in linguistic behaviour the personal theme is found contextually concealed from the hearer as contravened known facts (Danny's personal traits) in a hypothetical implicature for a predicative meaning of murder being an accident and not a 'coming about of crime' as a consequence of his alcohol problem. The theme of diminished responsibility is also intensified in a stylistically constructed binary pair of events when effects causing the murder are a factual one, but presented as a hypothetical other along with counterfactual inferences in offender discourse. Such is the analysis of the offender theme in Danny's account.

Open Access This article is distributed under the terms of the Creative Commons Attribution 4.0 International License (http://creativecommons.org/licenses/by/4.0/), which permits unrestricted use, distribution, and reproduction in any medium, provided you give appropriate credit to the original author(s) and the source, provide a link to the Creative Commons license, and indicate if changes were made.

\section{Appendix}

\section{Case study: Lifer Danny Morgan's Narrative in Life after life by Tony Parker (1990: Chapter 1)}

\section{Extract a Context: the state of NOT being a criminal}

p. 6-10

1. I'd never been in prison before in my life for anything, and I shall never go back to prison again because I'm not what could be called criminal sort of person. ... 3. I used to steal sweets from shops but I mean all kinds do that don't they? ... 4. it wasn't anything big if you know what I mean. 5. Most kids do little things: some get caught and some don't, that's all it amounts to really. 
6. it wasn't anything big if you know what I mean. ... 9. I' $d$ say myself what happened was mostly an accident really, in the sense I didn't mean to kill him. ... 15. - Last time, talking about being sad. .... I think this is the right way to look at it. 16. I am sorry he's dead because I liked him, but ... like I said I look on it it was like an accident, something that could have happened to anyone. - 17. Which do I mean could have happened to anyone, the killing or the being killed? 18. Well both I suppose. 19. I mean the scissors lying there on the table, they needn't have been. 20. It could have been a spoon or something. 21. Or them sticking into him where they did in his neck, it could just as well have been his shoulder or his chest or somewhere round here where it couldn't have done the same damage. 22. Or I suppose if I hadn't drunk a whole can of beer a bit earlier. 23. That was all it needed with me, I was fourteen and I had no head for it at all, one pint and I'd be under the Table. 24. So if I'd had less to drink, or even if I'd had more to drink and been incapable, I probably wouldn't have done it either way would I? 25. yes or if he'd given me the pocket money, you could say that's true as well. 26. I wouldn't say I was quick tempered person - normally no, I mean that's one thing it did teach me at St Andrews, how to keep your temper under control. ... 37. I mean I was guilty wasn't I, there couldn't really be an argument about it.

Extract b Context: Criminality (the state of being a criminal)

p. 11

... 40. Well I didn't know, did I? 41. I thought that was why they'd sent me there, to find out. 42. But I couldn't tell them, and they couldn't tell me, so the question never got answered did it? 43. Now ... I am the sort of person who if he's in a situation, a job, a prison sentence or whatever it is, he likes to get on with it to the best of his ability and not have hassle or give it either. ... 44. If people take me like I am, I won't give anybody trouble, I'll be polite and cheerful and well behaved from morning till night... at St Andrews ... the staff ... were always trying to quarrel with you or upset you: .... ...

p. 12

45. I could never see what good it was, and I either used to lose my temper or just switch off.

\section{Extract C Context: Not being in control}

27. I ran out of the house because I was very very frightened. 28. I ran like buggery. - 29. I ran into the woods [near my house]. 30. I wasn't really hiding or anything. 31. I think I was mostly in what they call a state of shock is it? 32. One of the things I've never worked out in my mind is why the police didn't come looking for me. 33. They'd easily have found me.

p. 9 
34. I was taken off to a remand centre, and kept in custody to await trial. 35. I got very very impatient because they kept taking me to court and having me remanded again, and I wanted to get on with it and have it over.

- 36. I pleaded guilty. 37. I mean I was guilty wasn't I, there couldn't really be an argument about it.

[At St Andrews treatment centre, it was encouraged everyone lose their tempers and shout and scream. Danny Morgan was repeatedly asked,]

p. 10

38. Why did you kill your grandfather? 39. Well yes they were always asking me that one. 40. Well I didn't know, did I? 41. I thought that was why they'd sent me there, to find out. 42. But I couldn't tell them, and they couldn't tell me, so the question never got answered did it?

p. 11

... 43. Now ... I am the sort of person who if he's in a situation, a job, a prison sentence or whatever it is, he likes to get on with it to the best of his ability and not have hassle or give it either. ... 44. If people take me like I am, I won't give anybody trouble, I'll be polite and cheerful and well behaved from morning till night... at $\overline{S t}$ Andrews ... the staff ... were always trying to quarrel with you or upset you: .......

p. 12

45. I could never see what good it was, and I either used to lose my temper or just switch off. ...

p. 13

47. I liked the people who ran it, they were straight down the line people: you don't give us no trouble and we won't give any to you.

Table 3: Extract a Theme: Contextualising a state of NOT being a criminal

Note: M (Medium), P (Process), C (Circumstance), A (Actor), G (Goal), In (Initiator), Instigator

- Linguistic expressions in italics and in bold is to draw analyst's attention.

- Processes are underlined to distinguish participant (Actor, Medium) and C in clauses

\begin{tabular}{|c|c|c|c|}
\hline Clauses & $\begin{array}{l}\text { Discourse features: } \\
\text { Factual, Counterfactual, } \\
\text { Hypothetical elements } \\
\text { Rhetorical questions } \\
\text { Tense aspects }\end{array}$ & Participant & $\begin{array}{l}\text { Vantage point: } \\
\text { Experiencing } \\
\quad \text { self } \\
\text { Binary event } \\
\text { Sub worlds }\end{array}$ \\
\hline $\begin{array}{l}\text { 1. I'd never been in prison } \\
\text { before in my life for } \\
\text { anything, and I shall } \\
\text { never go back to prison } \\
\text { again because I'm not } \\
\text { what could be called } \\
\text { criminal sort of person }\end{array}$ & $\begin{array}{l}\text { Factual premise: } \\
\text { I 'd never been } \\
\text { Hypotheticality: futurity: } \\
\text { Shall never } \\
\text { Could be called } \\
\text { Counterfactual: Negation }\end{array}$ & $\begin{array}{l}\mathrm{M}+\mathrm{P}+\mathrm{C}, \\
\text { And } \mathrm{A} \\
\quad \text { (Initiator) }+\mathrm{P}+\mathrm{C} \\
\text { Because } \mathrm{C}+\mathrm{C} \\
\text { Participant: } \\
\text { Medium } \\
+\end{array}$ & $\begin{array}{l}\text { Binary pair of } \\
\text { events } \\
\text { (A factual self } \\
\quad+ \\
\text { hypothetical } \\
\text { other with } \\
\text { counterfactual }\end{array}$ \\
\hline
\end{tabular}




\begin{tabular}{|c|c|c|c|}
\hline Clauses & $\begin{array}{l}\text { Discourse features: } \\
\text { Factual, Counterfactual, } \\
\text { Hypothetical elements } \\
\text { Rhetorical questions } \\
\text { Tense aspects }\end{array}$ & Participant & $\begin{array}{l}\text { Vantage point: } \\
\text { Experiencing } \\
\quad \text { self } \\
\text { Binary event } \\
\text { Sub worlds }\end{array}$ \\
\hline & & Actor (Intransitive) & $\begin{array}{l}\text { inference in } \\
\text { negation) }\end{array}$ \\
\hline $\begin{array}{l}\text { 3. I used to steal sweets } \\
\text { from shops but I mean } \\
\text { all kinds do that don't } \\
\text { they? }\end{array}$ & Rhetorical question & $\begin{array}{l}\text { Actor (Initiator) }+\mathrm{P}+\mathrm{G} \\
\text { But } \mathrm{S}+\mathrm{P}+\mathrm{C} \\
\text { Double dipping: } \\
\text { (multi foci) } \\
\text { Participant: } \\
\text { Actor (Transitive) } \\
+ \\
\text { Senser } \\
\text { (an experiencing self for } \\
\text { low topicality of } \\
\text { criminality) }\end{array}$ & $\begin{array}{l}\text { Experiencing } \\
\text { self } \\
\text { Epistemic sub } \\
\text { world of self- } \\
\text { belief }\end{array}$ \\
\hline $\begin{array}{l}\text { 4. It wasn't anything big if } \\
\text { you know what I mean }\end{array}$ & $\begin{array}{l}\text { Counterfactuality: } \\
\text { Conditional if } \\
\text { Negation }\end{array}$ & $\begin{array}{l}\text { Participant: } \\
\text { Senser } \\
\text { (Elaboration of cl. } 3 \text { : } \\
\mathrm{C}+\mathrm{S} \text { (you) }+\mathrm{P} \text { (Know) } \\
\text { negating the criminal self } \\
\text { with counterfactual } \\
\text { inferences) }\end{array}$ & $\begin{array}{l}\text { Experiencing } \\
\text { self } \\
\text { Epistemic sub } \\
\text { world of self } \\
\text { belief }\end{array}$ \\
\hline $\begin{array}{l}\text { 9. I 'd say myself what } \\
\text { happened was mostly an } \\
\text { accident really, in the } \\
\text { sense I didn't mean to } \\
\text { kill him }\end{array}$ & $\begin{array}{l}\text { Counterfactuality: } \\
\text { Negation } \\
\text { Hypotheticality: futurity } \\
\text { would }\end{array}$ & $\begin{array}{l}\mathrm{A}+\mathrm{P}+\mathrm{C}, \\
\mathrm{C}+\mathrm{S}+\mathrm{P} \\
\text { Double dipping: } \\
\text { Participants: } \\
\text { Actor (Intransitive) } \\
+ \\
\text { Senser } \\
\text { (low topicality to evaluate } \\
\quad \text { murder as accident) }\end{array}$ & $\begin{array}{l}\text { A Hypothetical } \\
\text { other with } \\
\text { counterfactual } \\
\text { inferences } \\
\text { Binary pair of } \\
\text { events } \\
\text { Deontic sub } \\
\text { world (would) } \\
\text { of obligation }\end{array}$ \\
\hline $\begin{array}{l}\text { 15.-Last time, talking } \\
\text { about being sad. .... I } \\
\text { think this is the right } \\
\text { way to look at it }\end{array}$ & $\begin{array}{l}\text { Present valued against the } \\
\text { past }\end{array}$ & $\begin{array}{l}\mathrm{C}+\mathrm{S}+\mathrm{P}+\mathrm{C} \\
\text { Participant: } \\
\text { Senser } \\
\text { (for low topicality when } \\
\quad \text { evaluating murder) }\end{array}$ & $\begin{array}{l}\text { Experiencing } \\
\text { self } \\
\text { Epistemic- } \\
\text { oriented world } \\
\text { view of self- } \\
\text { belief }\end{array}$ \\
\hline
\end{tabular}




\begin{tabular}{|c|c|c|c|}
\hline Clauses & $\begin{array}{l}\text { Discourse features: } \\
\text { Factual, Counterfactual, } \\
\text { Hypothetical elements } \\
\text { Rhetorical questions } \\
\text { Tense aspects }\end{array}$ & Participant & $\begin{array}{l}\text { Vantage point: } \\
\text { Experiencing } \\
\quad \text { self } \\
\text { Binary event } \\
\text { Sub worlds }\end{array}$ \\
\hline $\begin{array}{l}\text { 17. Which do I mean could } \\
\text { have happened to } \\
\text { anyone, the killing or the } \\
\text { being killed? }\end{array}$ & $\begin{array}{l}\text { Hypotheticality: } \\
\text { could (a probability) } \\
\text { Rhetorical question }\end{array}$ & $\mathrm{S}+\mathrm{P}$ & $\begin{array}{l}\text { Experiencing } \\
\text { self } \\
\text { Deontic sub } \\
\text { world (could) } \\
\text { for obligation }\end{array}$ \\
\hline 18. Well both I suppose & & $\begin{array}{l}\mathrm{S}+\mathrm{P} \\
\text { Participant: } \\
\text { Senser } \\
\text { (for low topicality of } \\
\text { social conditions to } \\
\text { perceive the completed } \\
\text { action of killing as a } \\
\text { possibility in cl. 17) }\end{array}$ & $\begin{array}{l}\text { Experiencing } \\
\text { self } \\
\text { Epistemic sub } \\
\text { world for self- } \\
\text { belief }\end{array}$ \\
\hline $\begin{array}{l}\text { 19. I mean the scissors } \\
\text { lying there on the table, } \\
\text { they needn't have been, }\end{array}$ & $\begin{array}{l}\text { Counterfactual: negation } \\
\text { (when factually the } \\
\text { scissors were present!) } \\
\text { Progressive aspect as } \\
\text { factual possibility }\end{array}$ & $\begin{array}{l}\mathrm{S}+\mathrm{P}+\mathrm{C} \\
\text { Participant: } \\
\text { Senser }\end{array}$ & $\begin{array}{l}\text { Experiencing } \\
\text { self } \\
\text { Binary pair of } \\
\text { events }\end{array}$ \\
\hline $\begin{array}{l}\text { 20. It could have been } \\
\text { spoon or something }\end{array}$ & $\begin{array}{l}\text { Hypotheticality: } \\
\text { in futurity, could have } \\
\text { been }\end{array}$ & $\mathrm{C}$ & $\begin{array}{l}\text { Binary pair of } \\
\text { events } \\
\text { Deontic sub } \\
\text { world (could) } \\
\text { of obligation }\end{array}$ \\
\hline $\begin{array}{l}\text { 21. Or them sticking into } \\
\text { him where they did in his } \\
\text { neck, it could just as } \\
\text { well have been his } \\
\text { shoulder or his chest or } \\
\text { somewhere round here } \\
\text { where it couldn't have } \\
\text { done the same damage }\end{array}$ & $\begin{array}{l}\text { Hypotheticality: } \\
\text { in futurity, could ... well } \\
\text { have been } \\
\text { Counterfactuality: } \\
\text { Negation } \\
\text { Progressive aspect } \\
\text { for proposition to be a } \\
\text { factual possibility and } \\
\text { form causation [7] as a } \\
\text { necessary condition, } \\
\text { which is an effect } \\
\text { necessary to justify/ } \\
\text { instigate/trigger the } \\
\text { killing }\end{array}$ & $\mathrm{C}$ & $\begin{array}{l}\text { Binary pair of } \\
\text { events } \\
\text { Deontic sub } \\
\text { world of } \\
\text { obligation }\end{array}$ \\
\hline
\end{tabular}




\begin{tabular}{|c|c|c|c|}
\hline Clauses & $\begin{array}{l}\text { Discourse features: } \\
\text { Factual, Counterfactual, } \\
\text { Hypothetical elements } \\
\text { Rhetorical questions } \\
\text { Tense aspects }\end{array}$ & Participant & $\begin{array}{l}\text { Vantage point: } \\
\text { Experiencing } \\
\quad \text { self } \\
\text { Binary event } \\
\text { Sub worlds }\end{array}$ \\
\hline $\begin{array}{l}\text { 22. Or I suppose if I } \\
\text { hadn't drunk a whole } \\
\text { can of beer a bit earlier }\end{array}$ & $\begin{array}{l}\text { Counterfactual: } \\
\text { conditional if negation }\end{array}$ & $\begin{array}{l}\mathrm{S}+\mathrm{P} \\
\text { If } \mathrm{M}+\mathrm{P}+\mathrm{C} \\
\text { Double dipping: } \\
\text { Participant: } \\
\text { Senser } \\
+ \\
\text { Medium } \\
\text { (In Medium role, the } \\
\text { theme of, 'feeding one's } \\
\text { habit' becomes } \\
\text { prominent - } \\
\text { an External cause that } \\
\text { triggered the killing) }\end{array}$ & $\begin{array}{l}\text { Binary pair of } \\
\text { events } \\
\text { Epistemic sub } \\
\text { world for self- } \\
\text { belief }\end{array}$ \\
\hline $\begin{array}{l}\text { 23. That was all it needed } \\
\text { with me, I was fourteen } \\
\text { and I had no head for it } \\
\text { at all, one pint and I'd } \\
\text { be under the table }\end{array}$ & $\begin{array}{l}\text { Factual premise: } \\
\text { in Perfective aspect which } \\
\text { denotes a completed } \\
\text { action } \\
\text { Admitting to the effects of } \\
\text { alcoholism }\end{array}$ & $\begin{array}{l}\mathrm{C}, \mathrm{A}+\mathrm{P} \text { (Intransitive) } \\
\text { And } \mathrm{M}+\mathrm{P}+\mathrm{C}, \\
\mathrm{C}+\mathrm{M}+\mathrm{P}+\mathrm{C} \\
\text { Double dipping: } \\
\text { Participant: } \\
\text { Actor (Intransitive) } \\
+ \\
\text { Medium } \\
\text { Medium role topicalizes } \\
\text { the effects of drinking }\end{array}$ & $\begin{array}{l}\text { Factual } \\
\text { premise }\end{array}$ \\
\hline $\begin{array}{l}\text { 24. So if I'd had less to } \\
\text { drink, or even if I'd had } \\
\text { more to drink and been } \\
\text { incapable, I probably } \\
\text { wouldn't have done it } \\
\text { either way would I? }\end{array}$ & $\begin{array}{l}\text { Counterfactuality: } \\
\text { conditional 'if' for } \\
\text { countering his drink habit } \\
\text { Hypotheticality: } \\
\text { in futurity } \\
\text { Rhetorical question }\end{array}$ & $\begin{array}{l}\text { If } \mathrm{A}+\mathrm{P} \text { (Intransitive) } \\
\text { If } \mathrm{A}+\mathrm{P}+\mathrm{C} \\
\quad \text { (Intransitive) } \\
\mathrm{A}+\mathrm{P}+\mathrm{C} \text { (intransitive) } \\
\text { Participant: } \\
\text { Actor (Intransitive) } \\
\text { Additional functions: } \\
\text { Both Agent }+ \text { Medium } \\
\text { The circumstance of being } \\
\text { alcoholic surrounding } \\
\text { the additional functions } \\
\text { Similar effect in cl. } 27 \text { and } \\
28 \text { in extract c. }\end{array}$ & $\begin{array}{l}\text { Binary pair of } \\
\text { events } \\
\text { Deontic sub } \\
\text { world (would) } \\
\text { of obligation }\end{array}$ \\
\hline $\begin{array}{l}\text { 25. Yes or if he'd given me } \\
\text { the pocket money, you } \\
\text { could say that's true as } \\
\text { well }\end{array}$ & $\begin{array}{l}\text { Counterfactual: } \\
\text { conditional } \\
\text { Hypotheticality: } \\
\text { futurity could }\end{array}$ & $\begin{array}{l}\text { If } \mathrm{A}+\mathrm{P}+\mathrm{O}^{\mathrm{di}} \\
\quad(\mathrm{me})+\mathrm{O}^{\mathrm{In}} \text { (money) } \\
\text { Participant: } \\
\text { Actor (Transitive) } \\
\text { (he-grandpa) }\end{array}$ & $\begin{array}{l}\text { Binary pair of } \\
\text { event } \\
\text { Deontic sub } \\
\text { world of } \\
\text { obligation }\end{array}$ \\
\hline
\end{tabular}




\begin{tabular}{|c|c|c|c|}
\hline Clauses & $\begin{array}{l}\text { Discourse features: } \\
\text { Factual, Counterfactual, } \\
\text { Hypothetical elements } \\
\text { Rhetorical questions } \\
\text { Tense aspects }\end{array}$ & Participant & $\begin{array}{l}\text { Vantage point: } \\
\text { Experiencing } \\
\quad \text { self } \\
\text { Binary event } \\
\text { Sub worlds }\end{array}$ \\
\hline $\begin{array}{l}\text { 26. I wouldn't say I was } \\
\text { quick tempered } \\
\text { person-normally no, I } \\
\text { mean that's one thing it } \\
\text { did teach me at St } \\
\text { Andrews, how to keep } \\
\text { your temper under } \\
\text { control }\end{array}$ & $\begin{array}{l}\text { Counterfactuality: } \\
\text { In negation, countering his } \\
\text { quick temper as a trigger } \\
\text { factor for committing } \\
\text { crime }\end{array}$ & $\begin{array}{l}\mathrm{A}+\mathrm{P}+\mathrm{C} \text {, (Intransitive) } \\
\mathrm{S}+\mathrm{P}+\mathrm{C} \\
\text { Double dipping: } \\
\text { Participant: } \\
\text { Actor (Intransitive) } \\
+ \\
\text { Senser }\end{array}$ & $\begin{array}{l}\text { Binary pair of } \\
\text { event } \\
\text { Deontic sub } \\
\text { world (would) } \\
\text { of obligation }\end{array}$ \\
\hline $\begin{array}{l}\text { 37. I mean I was guilty } \\
\text { wasn't I, there couldn't } \\
\frac{\text { really }}{\text { about } \frac{\text { be an argument }}{i t}}\end{array}$ & $\begin{array}{l}\text { Counterfactuality: } \\
\text { Negation } \\
\text { Rhetorical question }\end{array}$ & $\begin{array}{l}\mathrm{S}+\mathrm{P} \\
\mathrm{M}+\mathrm{P}+\mathrm{C} \\
\text { Double dipping: } \\
\text { Participant: } \\
\text { Senser } \\
+ \\
\text { Medium }\end{array}$ & $\begin{array}{l}\text { Experiencing } \\
\text { self, } \\
\text { countering his } \\
\text { guilt } \\
\text { Deontic sub } \\
\text { world (could) } \\
\text { of obligation }\end{array}$ \\
\hline
\end{tabular}

Table 4: Extract b Theme: Contextualising Criminality (the state of being a criminal)

\begin{tabular}{|c|c|c|c|}
\hline Clauses & $\begin{array}{l}\text { Counterfactual or } \\
\text { hypothetical elements }\end{array}$ & $\begin{array}{l}\text { Textual function } \\
\text { (orientation) }\end{array}$ & Vantage point \\
\hline $\begin{array}{l}\text {.. 43. Now ... I am the sort } \\
\text { of person who if he's in a } \\
\text { situation, a job, a prison } \\
\text { sentence or whatever it is, } \\
\text { he likes to get on with it to } \\
\text { the best of his ability and } \\
\text { not have hassle or give it } \\
\text { either }\end{array}$ & $\begin{array}{l}\text { Counterfactuality: } \\
\text { conditional if } \\
\text { Negation } \\
\text { Countering in negation } \\
\text { the aggressor trigger: } \\
\text { if hassled, Danny can } \\
\text { flip (an effector Danny) }\end{array}$ & $\begin{array}{l}\mathrm{C}+\mathrm{C}+\mathrm{S}+\mathrm{P}+\mathrm{C} \\
\text { Participant: } \\
\text { Senser (undergoer) } \\
+ \\
\text { Effector-he } \\
\text { (an undergoer when } \\
\text { countering the actions of } \\
\text { an } \text { effector- he in } \\
\text { conditional element and } \\
\text { in negation }\end{array}$ & $\begin{array}{l}\text { Experiencing } \\
\quad \text { self }\end{array}$ \\
\hline $\begin{array}{l}\text { 44. If people take me like I } \\
\text { am, I won't give anybody } \\
\text { trouble, I'll be polite and } \\
\text { cheerful and well behaved } \\
\text { from morning till night... } \\
\text { at St Andrews ... the staff } \\
\text {... were always trying to } \\
\text { quarrel with you or upset } \\
\text { you: ........ }\end{array}$ & $\begin{array}{l}\text { Counterfactuality: } \\
\text { Negation } \\
\text { Hypotheticality: futurity } \\
\text { will }\end{array}$ & $\begin{array}{l}\mathrm{C}+\mathrm{A}+\mathrm{P}+\mathrm{C}, \\
\mathrm{A}+\mathrm{P}+\mathrm{C} \ldots+\mathrm{C} \\
\text { Participant: } \\
\text { Actor (Intransitive) }\end{array}$ & $\begin{array}{l}\text { Binary pair of } \\
\text { events } \\
\text { Deontic sub } \\
\text { world (will) } \\
\text { of obligation }\end{array}$ \\
\hline
\end{tabular}




\begin{tabular}{lllc}
\hline Clauses & $\begin{array}{l}\text { Counterfactual or } \\
\text { hypothetical elements }\end{array}$ & $\begin{array}{l}\text { Textual function } \\
\text { (orientation) }\end{array}$ & Vantage point \\
\hline $\begin{array}{l}\text { 45. I could never see what } \\
\text { good it was, and I either } \\
\text { used to lose my temper or }\end{array}$ & $\begin{array}{c}\text { Counterfactuality: } \\
\text { negation }\end{array}$ & $\begin{array}{l}\mathrm{A}+\mathrm{P}+\mathrm{C}, \\
\text { and } \mathrm{A}+\mathrm{P}+\mathrm{C}\end{array}$ & $\begin{array}{c}\text { Binary pair of } \\
\text { events }\end{array}$ \\
$\begin{array}{l}\text { just switch } \text { off. (cl. 23) } \\
\text { Participant: }\end{array}$ & Actor (Intransitive) & $\begin{array}{c}\text { Deontic } \text { sub } \\
\text { world } \\
\text { (could) of } \\
\text { obligation }\end{array}$ \\
\hline
\end{tabular}

\section{Table 5: Extract c Theme: Contextualising theme of 'not being in control'}

\begin{tabular}{|c|c|c|c|}
\hline Clauses & $\begin{array}{l}\text { Counterfactual or } \\
\text { hypothetical elements }\end{array}$ & $\begin{array}{l}\text { Textual function } \\
\text { (orientation) }\end{array}$ & Vantage point \\
\hline $\begin{array}{l}\text { 27. I ran out of the house } \\
\text { because I was very very } \\
\text { frightened }\end{array}$ & Factual premise & $\begin{array}{l}\mathrm{M}+\mathrm{P}+\mathrm{C} \\
\text { (An } \text { entity Medium } \\
\text { through whom the act of } \\
\text { running is actualized due } \\
\text { to killing being the } \\
\text { external cause to } \\
\text { instigate running } \\
+ \\
\text { Intransitive Actor with, } \\
\text { Additional participant } \\
\text { functions: } \\
\text { Both Agent + Medium }\end{array}$ & $\begin{array}{l}\text { Participant } \\
\text { functions: } \\
\text { Agency }+ \text { Medium }\end{array}$ \\
\hline 28. I ran like buggery & $\begin{array}{l}\text { External cause of } \\
\text { freight instigating the } \\
\text { running, also in cl. } 24 \\
\text { and } 27\end{array}$ & $\begin{array}{l}\mathrm{M}+\mathrm{P}+\mathrm{C} \\
+ \\
\text { Intransitive Actor with, } \\
\text { Additional Participant } \\
\text { functions: } \\
\text { Both Agent + Medium }\end{array}$ & $\begin{array}{l}\text { Participant } \\
\text { functions: } \\
\text { Agency }+ \text { Medium }\end{array}$ \\
\hline $\begin{array}{l}\text { 34. I was taken off to a } \\
\text { remand centre, and kept } \\
\text { in custody to await trial }\end{array}$ & $\begin{array}{l}\text { Notice passivity-was } \\
\text { taken off } \\
\text { NOT active: They took } \\
\text { me to a .... }\end{array}$ & $\begin{array}{l}\mathrm{M}+\mathrm{P}+\mathrm{C} \\
\text { And } \mathrm{P}+\mathrm{C} \\
\text { Entity with Medium role }\end{array}$ & $\begin{array}{l}\text { A narrative object } \\
\text { (Actor not in } \\
\text { control of its } \\
\text { situation) }\end{array}$ \\
\hline
\end{tabular}




\begin{tabular}{|c|c|c|c|}
\hline Clauses & $\begin{array}{l}\text { Counterfactual or } \\
\text { hypothetical elements }\end{array}$ & $\begin{array}{l}\text { Textual function } \\
\text { (orientation) }\end{array}$ & Vantage point \\
\hline $\begin{array}{l}\text { 35. I got very very } \\
\text { impatient because they } \\
\frac{\text { kept taking }}{\text { and }} \frac{\text { me to court }}{\text { having }} \frac{\text { me }}{\text { remanded again, and I }} \\
\frac{\text { wanted to get on with it }}{\text { and have it over }}\end{array}$ & $\begin{array}{l}\text { progressive tense } \\
\text { (See also cl. } 21 \text { and } 23 \text { ) }\end{array}$ & $\begin{array}{l}\mathrm{M}+\mathrm{P}+\mathrm{C} \\
\text { Because } \\
\quad \mathrm{A}+\mathrm{P}+\mathrm{O}^{\mathrm{di}}+\mathrm{C} \\
\text { And } \mathrm{P}+\mathrm{M}+\mathrm{C}, \\
\text { and } \mathrm{A}(\mathrm{In})+\mathrm{P}+\mathrm{C} \\
\text { Double dipping: } \\
\text { Participant: } \\
\text { Medium } \\
+ \\
\text { Actor (Initiator) } \\
\text { (Murder being the } \\
\text { external cause } \\
\text { surrounding Medium } \\
\text { participant function and } \\
\text { agent function of the } \\
\text { narrating-I) }\end{array}$ & $\begin{array}{l}\text { Participant } \\
\text { functions: } \\
\text { Agency + Medium }\end{array}$ \\
\hline 36. I pleaded guilty & & $\begin{array}{l}\mathrm{M}+\mathrm{P}+\mathrm{C} \\
\text { Additional Participant } \\
\text { functions: } \\
\text { Both Agency + Medium } \\
\text { (Murder committed as } \\
\text { external cause } \\
\text { surrounding participant } \\
\text { functions) }\end{array}$ & $\begin{array}{l}\text { Participant } \\
\text { functions: } \\
\text { Agency }+ \text { Medium }\end{array}$ \\
\hline $\begin{array}{l}\text { 47. I liked the people who } \\
\text { ran it, they were straight } \\
\text { down the line people: } \\
\text { you don't give us no } \\
\text { trouble and we won't } \\
\text { give any to you }\end{array}$ & $\begin{array}{l}\text { Repeated '... you don't } \\
\text { give us no trouble } \\
\text { and we won't give } \\
\text { any to you.' In cl. } \\
\text { clause } 44\end{array}$ & $\begin{array}{l}\mathrm{S}+\mathrm{P}, \\
\text { Ag/Instigator }+\mathrm{P}+\mathrm{C}: \mathrm{C} \\
\text { Double dipping } \\
\text { Participant: } \\
\text { Senser } \\
+ \\
\text { Agent (Instigator) }\end{array}$ & Experiencing self \\
\hline
\end{tabular}

\section{References}

1. Bloor, T., and M. Bloor. 2013. The Functional Analysis of English, 3rd ed, 13. Oxon: Routledge.

2. Bamberg, Michael, and Molly Andrews. 2004. Considering Counter-Narratives: Narrating, Resisting, Making Sense. Amsterdam, Philadelphia: John Benjamin.

3. Culler, Jonathan. 1981. The Pursuit of Signs: Semiotics, Literature, Deconstruction, 169-187. London and Henley: Routledge and Kegan Paul.

4. Dannenberg, Hilary P. 2008. Coincidence and Counterfactuality: Plotting Time and Space in Narrative Fiction. Lincoln and London: University of Nebraska Press.

5. Dannenberg, Hilary P. 2014. Gerald Prince and the Fascination of What Doesn't Happen. Narrative, 22:3 (October 2014). Copyright 2014 by Ohio State University. 
6. Dutta-Flanders, Reshmi. 2014 'Concealment and Revelation: an interdisciplinary approach to reader suspense', Style 48 (2) summer, pp. 219-242 and pp. 257-259. Available at: https://www.questia. com/library/p1129/style/i3785709/vol-48-no-2-summer Accessed 23 Oct 2015.

7. Dutta-Flanders, Reshmi. 2017. The Language of Suspense in Crime Fiction: A Linguistic Stylistic Approach. Palgrave Macmillan.

8. Enkvist, Nils Erik. 1973. Linguistic Stylistics, 11-26. The Hague, Paris: Mouton.

9. Feng, Zongxin. 2014. 'The logical nature of Systemic-Functional Grammar and "grammatical logic'. Journal of World Languages 1:3 232-241. Accessed 17 December 2014 @ 03.04. Routledge.

10. Halliday, M.A.K. 2004. An Introduction to Functional Grammar, 3rd ed. London: Hodder Arnold. (Revised by C. M. I. M. Matthiessen).

11. Halliday, M.A.K. 2014. Halliday's Introduction to Functional Grammar, 4th ed. London: Routledge. (Revised by C. M. I. M. Matthiessen).

12. Halliday, M.A.K. 1994. An Introduction to Functional Grammar, 2nd ed. London: Edward Arnold.

13. Harris, Sandra. 2005. Telling Stories and Giving Evidence: The Hybridisation of Narrative and Nonnarrative Modes of Discourse in Sexual Assault Trial. In The Sociolinguistics of Narrative, ed. Joana Thornborrow and Jennifer Coates. Amsterdam, Philadelphia: John Benjamins.

14. Howard, Richard, and Jonathan Culler. 1977. Tzvetan Todorov: The Poetics of Prose. Ithaca, New York: Cornell University Press.

15. Merkl-Davies, D.M., and N.M. Brennan. 2007. Discretionary Disclosure Strategies in Corporate Narratives: Incremental Information or Impression Management? Journal of Accounting Literature 26:116-196.

16. Polanyi, Livia. 1982. Literary Complexity in Everyday Storytelling. In Spoken and Written Language: Exploring Orality and Literacy, vol. IX, ed. Deborah Tannen, 155-169. Norwood, New Jersey: Ablex Publishing Corporation.

17. Ricoeur, Paul. 1985. Time and Narrative: Vol 2. Translated by Kathleen McLaughlin and David Pellauer, pp. 88-99. USA: The University of Chicago.

18. Sussex, L. 2010. Women Writers and Detectives in Nineteenth-Century Crime Fiction: The Mothers of the Mystery Genre. England: Palgrave Macmillan.

19. Thompson, Geoff. 1996. Introducing Functional Grammar. Arnold: Great Britain.

20. Todorov, T. 1987. The Poetics of Prose. Translated by Richard Howard and Jonathan Culler, pp. 43-52. Reprint. USA: Cornell University Press, 1977.

21. Ziegeler, Debra. 2012). The grammaticalization of modality. In The Oxford Handbook of Grammaticalization, eds. Bernd Heine and Heiko Narrog. Available at: www.oxfordhandbooks.com. Accessed 26th February 2015.

22. Ziegeler, Debra. 2000. Hypothetical Modality: Grammaticalisation in an L2 dialect. Amsterdam, Philadelphia: John Benjamins.

23. Ziegeler, Debra. 2006. Interfaces with English Aspect: Diachronic and Empirical Studies, 7. Amsterdam: John Benjamins.

24. Fagles, Robert. 1982. Sophocles: The Three Theban Plays Antigone, Oedipus the King, Oedipus at Colonus, 1st ed, 10, 14. Great Britain: Penguin Books, Allen Lane.

25. Gavins, Joanna. 2007. Text World Theory: an introduction. Edinburgh: Edinburgh Press. 